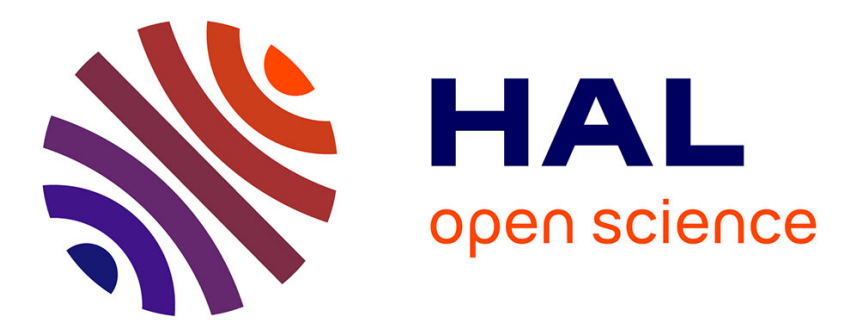

\title{
Characterizations of crystalline structure and catalytic activity of zwitterionic imidazole derivatives
}

S. Yebdri, O. Nehar, R. Mahboub, T. Roisnel, L. Boukli-Hacene, S. Louhibi

\section{To cite this version:}

S. Yebdri, O. Nehar, R. Mahboub, T. Roisnel, L. Boukli-Hacene, et al.. Characterizations of crystalline structure and catalytic activity of zwitterionic imidazole derivatives. Journal of Molecular Structure, 2019, 1193, pp.45-52. 10.1016/j.molstruc.2019.05.020 . hal-02161326

\section{HAL Id: hal-02161326 \\ https://hal-univ-rennes1.archives-ouvertes.fr/hal-02161326}

Submitted on 1 Jul 2019

HAL is a multi-disciplinary open access archive for the deposit and dissemination of scientific research documents, whether they are published or not. The documents may come from teaching and research institutions in France or abroad, or from public or private research centers.
L'archive ouverte pluridisciplinaire HAL, est destinée au dépôt et à la diffusion de documents scientifiques de niveau recherche, publiés ou non, émanant des établissements d'enseignement et de recherche français ou étrangers, des laboratoires publics ou privés. 
Graphical abstract

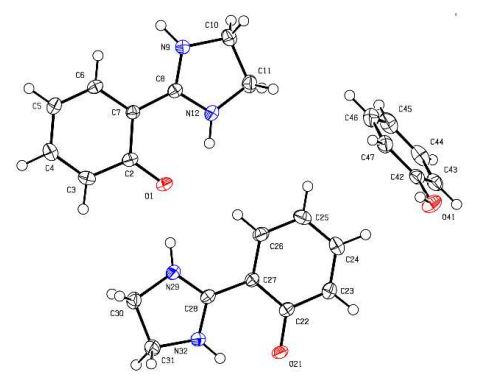

L1 crystal
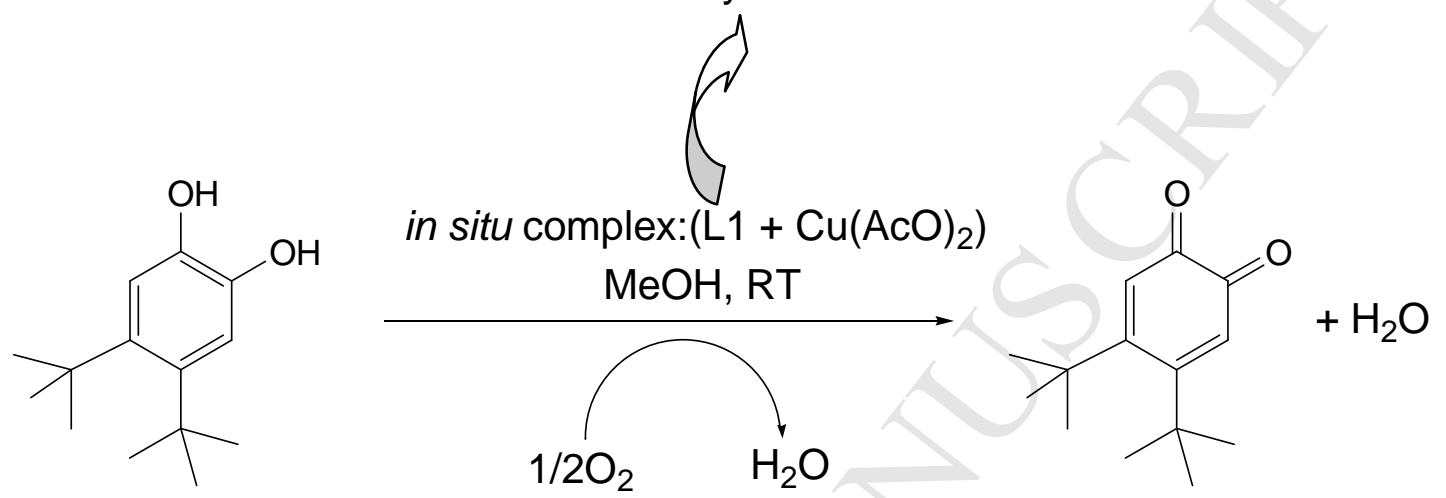

3,5-DTBC
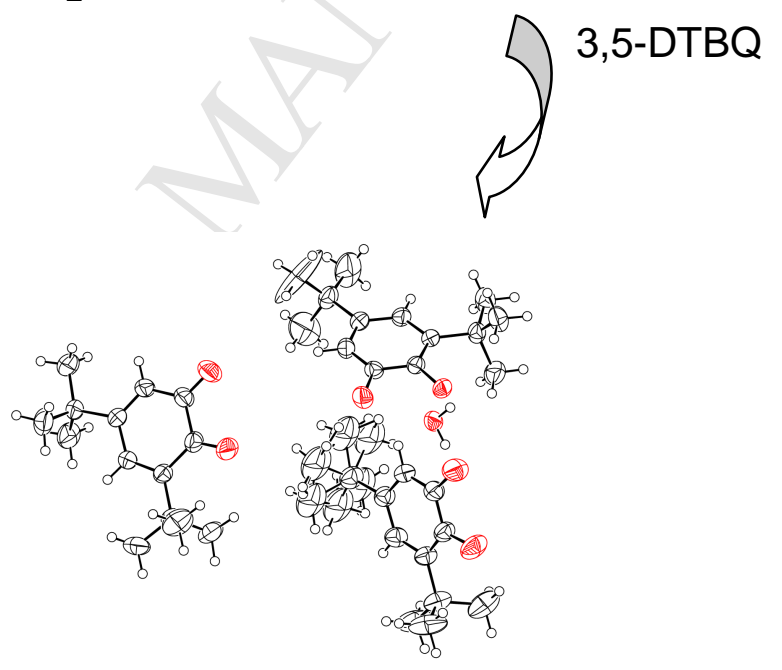

Q crystal 


\title{
Characterizations of crystalline structure and catalytic activity of zwitterionic imidazole derivatives
}

\author{
Sihem Yebedri ${ }^{\mathrm{a}}$, Oussama Nehar ${ }^{\mathrm{a}}$, Radia Mahboub $^{\mathrm{b}}$, Thierry Roisnel $^{\mathrm{c}}$, Leila Boukli-Hacene ${ }^{\mathrm{a}}$ and \\ Samira Louhibi ${ }^{\text {a,* }}$ \\ a: Laboratory of Inorganic and Environment Chemistry, University of Tlemcen,B.P. 119, 13000 Tlemcen, Algeria \\ ${ }^{\mathrm{b}}$ Department of Chemistry, Faculty of Sciences, University of Tlemcen, B.P. 119, Tlemcen, 13 000, Algeria. \\ e-mail: radiamahboub@yahoo.com \\ c : Center of Diffractometry X, UMR 6226 CNRS, University of Rennes 1, 35042 Rennes, France \\ Corressponding author*: samhibi1@yahoo.fr
}

\begin{abstract}
A B S T R A C T
The zwitterion ligand L1 has been synthesized and characterized by single-crystal X-ray diffraction, and spectroscopic techniques (1H, 13C NMR, FT-IR, ESI-MS, and UV-Vis). The crystal structure shows that L1 molecules are planar and are connected via intermolecular $\mathrm{N}$ $\mathrm{H}----\mathrm{O}$ and intramolecular N-H----O interactions. The NMR analysis shows the presence of two mesomeric forms of L1: zwitterion and ketone-imidazolidine. The kinetic study of in situ complexes is followed by UV-vis spectroscopy and revealed a binuclear structure built from square base pyramidal geometry and octahedral one. In situ complexes obtained from L1 with different copper (II) salts are studied for their catecholase activities using 3,5-di-tertbutylcatechol. The obtained 3,5-di-tert-butylquinone was characterized by single-crystal Xray diffraction,. The results show that the catalytic activity depends on the nature of the metal salt anion. From Michaelis-Menten model, we have evaluated the dissociation constant and the bond constant which are in good agreement with those of literature. The structure-activity relationship show that the high rate of catalytic oxidation depends on the presence of copper ion in the complex.
\end{abstract}

Keywords: Imidazole derivative; X-Ray; Zwetterionic form; Catechol oxidase

\section{Introduction}

Imidazole are of particular chemical and extensively studied molecules due to their applications as complexing agents [1,2].They not only represent an important class of pharmaceutical compounds [3, 4], but also known for their biological activities [5] and environmental applications[6, 7]. Imidazole derivatives like Imidazoline containing phenyl hydroxyl group have attracted the interest of chemists because of its applications [8-11] and tautomeric forms such as zwitterions. This zwitterionic form occurs by a proton transfer from ortho-hydroxy group to the nitrogen whose stability increase through the interactions between opposite charges [12].

Imidazole is known as model of the active site of catecholase function, and presents an important interest of the zwitterions ligand. Imidazole-based zwitterionic-type molten salt have been explored as a new class of organocatalyst in various chemical transformations. [13].

Considerable amount of studies are focused on the synthesis of complexes with several nitrogen containing ligands designed to model catecholase [14-17]. Their catalytic activity has been investigated as in situ complexes [18, 19] or isolated complexes [20,21]. Many of these studies concentrate on dinuclear complexes $[17,22]$, but also mononuclear complexes are also studied in the literature [23]. The properties of mono and binuclear $\mathrm{Cu}$ (II) complexes have also been compared $[24,25]$, the rates of catechol oxidation were found to be dependent on 
ligand type. As a result, studies have reported the use of in situ copper (II) complexes of Schiff base derivatives to produce catecholase activity [26].

In the present work, we report the synthesis of the 2-(1H-Imidazolin-2-yl)phenol, the crystalline structure of zwitterions L1 and its characterization by spectroscopic methods and single-crystal X-ray diffraction. Then, we study the catalytic activity of the in situ copperimidazole complex (CuL1) towards the oxidation of 3,5-di-tert-butylcatechol (3,5-DTBC). Finally, we discuss the structure-activity relationship.

\section{Experimental}

\subsection{Materials and Physical measurements}

Ethylene diamine, phenylsalicylate, dithertiobutyl catechol, $\mathrm{Cu}(\mathrm{AcO})_{2} \cdot \mathrm{H}_{2} \mathrm{O}, \mathrm{Cu}\left(\mathrm{NO}_{3}\right)_{2}$, $\mathrm{CuCl}_{2}$ and $\mathrm{CuSO}_{4}$ (Aldrich) were used as purchased. High-grade solvents (methanol, ethanol, dimethylformamide) were used without further purification.

IR spectra were measured in the $400-4000 \mathrm{~cm}^{-1}$ range on a 9800 FTIR spectrometer (Perkin-Elmer) where samples were run as $\mathrm{KBr}$ pellets. Kinetic measurements were made spectrophotometrically using a UV-Vis UV-1650 PC Shimadzo spectrophotometer. The Xray data was collected on a diffractometer APEXII, Bruker-AV III equipped with a graphite monochromator Mo-K $\alpha$ radiation $((\lambda=0.71073 \AA)$. The $1 \mathrm{H}$ NMR $(300 \mathrm{MHz})$ and $13 \mathrm{C}(300$ MHz) NMR spectra were recorded on a Bruker 300 spectrometer. Chemical shifts are listed in $\mathrm{ppm}$ and are reported relatively to tetramethylsilane using the methanol- $\mathrm{d}_{4}$ solvent. The deuterated methanol is identified by ${ }^{1} \mathrm{H}$ and ${ }^{13} \mathrm{C}$ peaks at $3.34 \mathrm{ppm}$ and $47.6 \mathrm{ppm}$ respectively. Mass analysis was done on a spectrometer LC/MSD-TOF 1969A dual source equipped with a lock spray (ESI-MS).

\subsection{Synthesis of 2-(4,5-dihydro-1H-imidazol-3-ium-2-yl)phenolate, phenol : L1 $\left[2\left(\mathrm{C}_{9} \mathrm{H}_{10} \mathrm{~N}_{2} \mathrm{O}\right), \mathrm{C}_{6} \mathrm{H}_{5} \mathrm{OH}\right]$}

Equimolar quantities of ethylenediamine $10^{-2} \mathrm{~mol}(0.6 \mathrm{~g})$ and phenylsalicylate $10^{-2}$ mol $(2.14 \mathrm{~g})$ were mixed and vigorously stirred at $110{ }^{\circ} \mathrm{C}$ under oil bath for $5 \mathrm{~h}$. Brown crystals suitable for X-ray diffraction analysis was obtained after slow evaporation of the L1 solution $\left(2\left(\mathrm{C}_{9} \mathrm{H}_{10} \mathrm{~N}_{2} \mathrm{O}\right), \mathrm{C}_{6} \mathrm{H}_{5} \mathrm{OH}\right)$. Mp: $244{ }^{\circ} \mathrm{C}$.

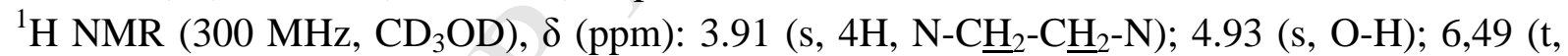
$1 \mathrm{H}) ; 6.53(\mathrm{~d}, 2 \mathrm{H}) ; 6.47(\mathrm{~d}, 1 \mathrm{H}) ; 6.75(\mathrm{~d}, 1 \mathrm{H}) ; 6.80(\mathrm{t}, 2 \mathrm{H}) ; 7.15(\mathrm{~m}, 1 \mathrm{H}) ; 7.28(\mathrm{~m}, 1 \mathrm{H}, \mathrm{N}-\mathrm{H})$; 7,44 (d, 1H, N-H) ppm. ${ }^{13} \mathrm{C}$ NMR (300 MHz, CD $\left.3 \mathrm{OD}\right), \delta$ (ppm): 172.18 (Ar.-C1), 166.80 (C6H5-C8 imidazole), 157.02 (Ar.-C 13), 135.07 (Ar. C15, C17), 129.07 (Ar.-C3), 128.29 (Ar.-C4), 122.7 (Ar.-C2), 119.71 (Ar.-C5), 119.08 (Ar.-C16), 113.54 (Ar.-C6), 107.09 (Ar.C14, C18), $43.54\left(\mathrm{Imd}_{\underline{C}} \mathrm{H}_{2}, \mathrm{C} 10\right)$ and $\left(\mathrm{Imd}_{\underline{\mathrm{CH}}}{ }_{2}, \mathrm{C} 11\right) \mathrm{ppm}$. Selected IR bands (KBr pellet, $\left.\mathrm{cm}^{-1}\right): 3400(\mathrm{O}-\mathrm{H}) ; 1264(\mathrm{O}-\mathrm{H}) ; 1400\left(\mathrm{Ar}_{\mathrm{C}=\mathrm{C}}\right) 764\left(\mathrm{Ar}_{\mathrm{C}-\mathrm{H}}\right) ; 3420-3480$ (imidazole $\left._{\mathrm{N}-\mathrm{H}}\right) ; 1616$ (imidazole $\left._{\mathrm{C}=\mathrm{N}}\right)$. MS (ESI) m/z: $[\mathrm{M}+\mathrm{H}]^{+} 163$.

\subsection{Crystallographic data collection for $\mathrm{LI}$}

The crystallographic measurements of L1 was performed on APEXII Bruker-AXS diffractometer equipped with an Oxford Cryosystem Open-flow nitrogen cryostat, using a graphite-monochromated MoK $\alpha$ radiation $(\lambda=0.71073 \AA)$ at $150 \mathrm{~K}$.

The structure was solved by direct methods using the SIR97 program [27], and then refined with full-matrix least-square methods based on $F^{2}$ (SHELXL-97) [28] with the aid of the WINGX [29] program. All non-hydrogen atoms were refined with anisotropic atomic 
displacement parameters. The C-bonded hydrogen atoms were positioned geometrically and refined using a riding model, whereas nitrogen and oxygen linked hydrogen atoms were introduced in the structural model through Fourier difference maps analysis. A final refinement on $F 2$ with 4659 unique intensities and 295 parameters converged at $\omega R(F 2)=$ $0.0992(\mathrm{R}(\mathrm{F})=0.0383)$ for 3904 observed reflections with $\mathrm{I}>2 \sigma(\mathrm{I})$. Details of the crystal data, data collection and refinement process are listed in Table 1.

\subsection{Catecholase activity measurements}

The formation of 3,5-di-tert-butylquinone (3,5-DTBQ, $\lambda \max =400 \mathrm{~nm}$ and $\varepsilon=1900$ $\left.\mathrm{M}^{-1} \mathrm{~cm}^{-1}\right)$ was carried out by four complexes $\left(\mathrm{Cu}(\mathrm{AcO})_{2} / \mathrm{L} 1, \mathrm{Cu}\left(\mathrm{SO}_{4}\right) / \mathrm{L} 1, \mathrm{CuCl}_{2} / \mathrm{L} 1\right.$ and $\left.\mathrm{Cu}\left(\mathrm{NO}_{3}\right)_{2} / \mathrm{L} 1\right)$ formed in situ at $25{ }^{\circ} \mathrm{C}$ in methanol in presence of air, from acetate, sulfate, chloride and nitrate metal salts. The manipulations are performed on different solutions: the concentration of complex is equal to $10^{-4}$ mol. $\mathrm{L}^{-1}$ and that of $3,5-\mathrm{DTBC}$ varies from $10^{-2}$ to $7.10^{-2}$ mol. $\mathrm{L}^{-1}$ (ie 100 to 700 equivalents to the complex). An equimolar mixture of metal salt $\left(\mathrm{CuX}_{2}, \mathrm{nH}_{2} \mathrm{O}: \mathrm{X}=\mathrm{CH}_{3} \mathrm{COO}^{-}, \mathrm{SO}_{4}{ }^{2-}, \mathrm{Cl}^{-}\right.$and $\mathrm{NO}_{3}^{-}, \mathrm{n}=1,0,2$ and 5 respectively $)$ and ligand L1 is pooled with 3,5-DTBC to catalyze its oxidation [30]. Also, experiments of the rate dependence on substrate concentration in the absence of catalyst were performed at the same concentration conditions. The values obtained were subtracted from those obtained in the presence of catalysts.

\section{Results and discussion}

\subsection{Proposed reaction pathway}

The synthesis of 2-(1H-Imidazolin-2-yl) phenol has been widely reported by the authors in the literature [31-34]. In this work, we have realized this condensation reaction between ethylenediamine and phenyl salicylate. At high temperature, the double condensation onto the diamine does not occur. The formation of imidazoline is realized in three steps: i) substitution of phenol with ethylenediamine, ii) followed by autocyclisation iii) and elimination of water. After evaporation, we have obtained the crystal of ligand L1.

The progressive evaporation of water molecules promotes the crystallization of L1 in its most stable tautomer form ketone-imidazolidine. After total elimination of water, the last form is changed by transferring the proton from phenol to imine and adopts the zwitterionic form. We propose the following mechanism given in Scheme 1. 

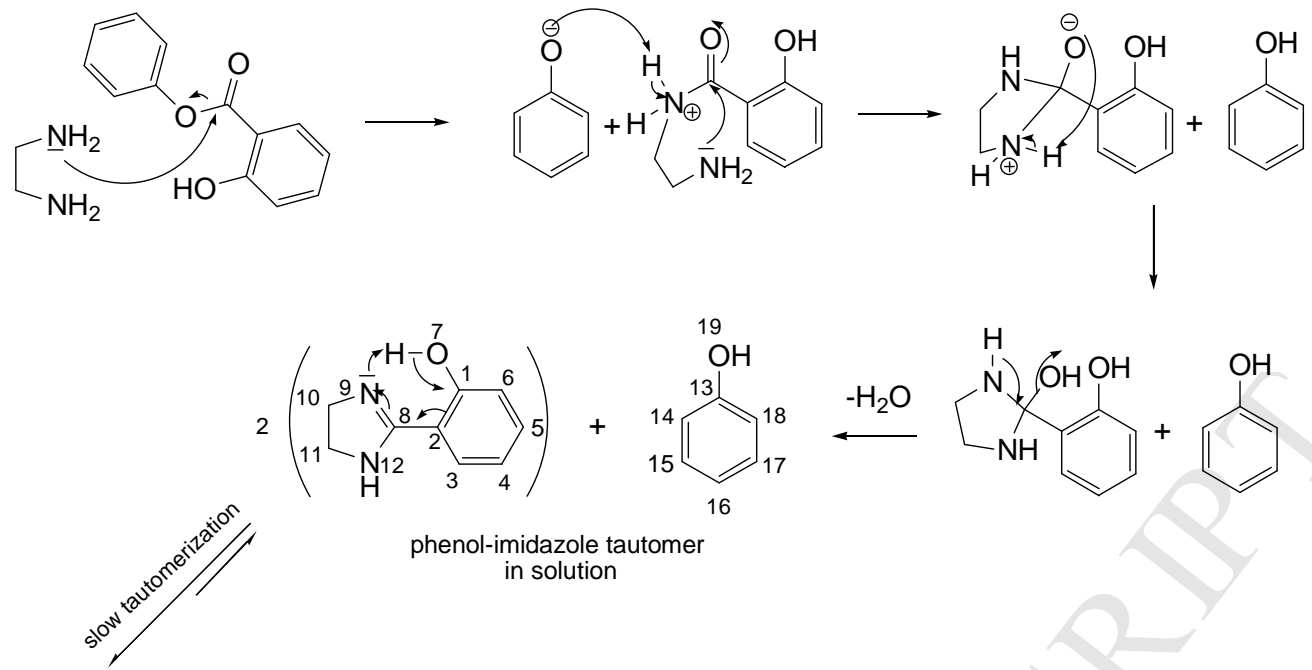

phenol-imidazole tautomer in solution
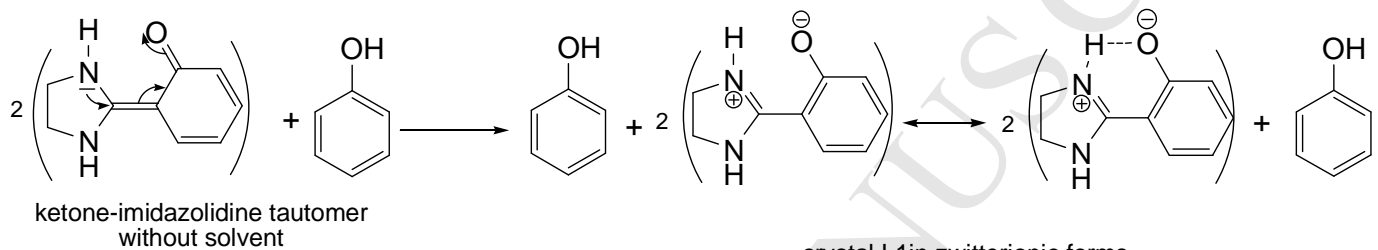

crystal L1in zwitterionic forms

Scheme 1. Proposed reaction pathway for obtaining of zwitterionic imidazole crystal L1.

\subsection{Crystallographic studies of $L 1$}

The main crystal parameters are reported in Table 1. Structure of L1 with numbering scheme is illustrated in Fig. 1. L1 is crystallized in a triclinic space group P-1 and with a two unit per cell $(\mathrm{Z}=2)$. The structure of $\mathrm{L} 1$ is build by an asymmetric unit containing one phenol molecule and two phenol-imidazole molecules. The carbon atoms $\left(C_{31}\right.$ and $\left.C_{10}\right)$ in the imidazole rings are nearly coplanar with the largest deviations from the middle plan being 0.0942(13) $\AA$ for $\mathrm{C}_{31}$ and $0.0807(13) \AA$ for $\mathrm{C}_{10}$ (Fig1.).

The phenol-imidazole molecule is relatively planar. Therefore, for the $\mathrm{C}_{27}-\mathrm{C}_{28}$ and $\mathrm{C}_{7-}$ $\mathrm{C}_{2}$ bonds, the atom pairs $\left(\mathrm{N}_{32} / \mathrm{C}_{22}, \mathrm{C}_{28} / \mathrm{C}_{27}\right)$ and $\left(\mathrm{O}_{1} / \mathrm{C}_{8}, \mathrm{C}_{2} / \mathrm{C}_{7}\right)$ are all cis, shown by the torsion angle values of $1.27(16)^{\circ}$ for $\mathrm{C}_{22}-\mathrm{C}_{27}-\mathrm{C}_{28}-\mathrm{N}_{32}$ and $2.84(14)^{\circ}$ for $\mathrm{O}_{1}-\mathrm{C}_{2}-\mathrm{C}_{7}-\mathrm{C}_{8}, 3.50$ $(16)^{\circ}$. As consequence, this entity adopts $Z$ configuration (Fig.1).

From the data analysis, we note that the imidazole ring shows two characteristic situations of the five-membered rings. Consequently, the geometry revealed that endocyclic angles vary from $103.40(9)^{\circ}$ to $112.02(9)^{\circ}$ assigned respectively to $\mathrm{N}_{9}-\mathrm{C}_{10^{-}}-\mathrm{C}_{11}$ and $\mathrm{C}_{8}-\mathrm{N}_{12^{-}}$ $\mathrm{C}_{11}$. While the exocyclic angles are obtuse smallest being $117.7(11)^{\circ}$ for $\mathrm{C}_{28^{2}}-\mathrm{N}_{32}-\mathrm{H}_{32}$ and the largest 131.1(10) ${ }^{\circ}$ for $\mathrm{C}_{11}-\mathrm{N}_{12}-\mathrm{H}_{12}$ (Fig.1). Our results are in good agreement with those of literature [35].

The crystal structure of ligand L1 is determined by different inter and intra molecular interactions which are given in Table 2. These are considered as a competition between short inter and inter molecular $\mathrm{N}-\mathrm{H} . . \mathrm{O}$ (and $\mathrm{O}-\mathrm{H} . . . \mathrm{O}$ ) interactions and long-range intermolecular $\mathrm{H}-\mathrm{N} . . . \mathrm{O}$ (and $\mathrm{H}-\mathrm{O} \ldots \mathrm{O}$ ) interactions. Thus, these interactions influence the geometry of this crystal.

From figure 2, we observe that the three molecules in L1 (one phenol and two phenolimidazole) are combined to form a $\pi$-stacked staircase arrangement. Thus, the structure o L1 is stabilized by five hydrogen bonds: i) two $\mathrm{H}$ bonds an intramolecular interaction: $\mathrm{N}_{12}-$ $\mathrm{H}_{12} \ldots \mathrm{O}_{1}$ and $\mathrm{N}_{32}-\mathrm{H}_{32} \ldots \mathrm{O}_{21}\left(\mathrm{O}_{\text {phenolate }} . . \mathrm{H}-\mathrm{N} 1_{\text {imd }}\right)$ (entries 2 and 4, Table 2), ii) two 
intermolecular $\mathrm{H}$ bonds: $\mathrm{N}_{9}-\mathrm{H}_{9} \ldots \mathrm{O}_{21}$ and $\mathrm{N}_{29}-\mathrm{H}_{29} \ldots \mathrm{O}_{1}\left(\mathrm{O} 1_{\text {phenolate }} \ldots \mathrm{H}-\mathrm{N} 2_{\text {imd }}\right)$ (entries 1 and 3 , Table 2) and iii) one intermolecular $\mathrm{H}$ bond: $\mathrm{O}_{41}-\mathrm{H}_{41} \ldots \mathrm{O}_{21}\left(\mathrm{O}_{\text {phenolate }} \ldots \mathrm{H}-\mathrm{O}-\mathrm{Ar}\right)$ (entry 5, Table 2).

In the $\mathrm{L} 1$ structure, the $\mathrm{N}-\mathrm{H} \ldots \mathrm{O}$ hydrogen bonds $\left(\mathrm{N}_{9}-\mathrm{H}_{9} \ldots \mathrm{O}_{21}=1.875 \AA, \mathrm{N}_{12}-\mathrm{H}_{12}-\mathrm{O}_{1}\right.$ $\left.=1.843 \AA, \mathrm{N}_{29}-\mathrm{H}_{29} \ldots \mathrm{O}_{1}=1.826 \AA, \mathrm{N}_{32}-\mathrm{H}_{32}-\mathrm{O}_{21}=1.903 \AA\right)$ and Ar-O-H..O H bond $\left(\mathrm{O}_{41}-\right.$ $\mathrm{H}_{41} \ldots \mathrm{O}_{21}=1.744 \AA$ ) organize molecules into a three-dimensional sample, and the H-N...O interactions $\left(\mathrm{H}-\mathrm{N}_{9} \ldots \mathrm{O}_{21}=2.795 \AA, \mathrm{H}-\mathrm{N}_{12} \ldots \mathrm{O}_{1}=2.585 \AA, \mathrm{H}-\mathrm{N}_{29} \ldots \mathrm{O}_{1}=2.730 \AA, \mathrm{H}-\mathrm{N}_{32} \ldots \mathrm{O}_{21}\right.$ $=2.621 \AA)$ with $\mathrm{H}-\mathrm{O} \ldots \mathrm{O}$ interaction $\left(\mathrm{H}-\mathrm{O}_{41} \ldots \mathrm{O}_{21}=2.672 \AA\right)$ confirm the strong of the L1 crystal architecture (Fig. 2).

The displacement of protons from phenolic oxygen to the nitrogen atom of imidazole generates the zwitterionic phenolate form (Scheme 1) and proves it presence in the crystal L1 (Fig.1). Thus, the amine hydrogen participate in a strong intramolecular hydrogen bond with the phenolate oxygen atom and generate an $\mathrm{R}$ (6) ring motif. These two six-membered pseudocycles are approximately planar. The cohesion of the crystal L1 is realized by the presence of intermolecular hydrogen bonds $\left(\mathrm{NH} \ldots \mathrm{O}_{\text {phenolate }}\right)$ and produces a graph-set motif $\mathrm{C}_{2}^{2}$ (3) (Fig.2).

Moreover, the phenol molecules are located between two layers of imidazoles. As a result, they contribute to the formation of a three-dimensional network by the hydrogen bonds $\mathrm{O}_{41}-\mathrm{H}_{41} \ldots \mathrm{O}_{21}$ (Fig. 2.). From figure 2, we estimated the centroid-centroid and the slippage distances of phenol-phenol which are respectively 3.5635(7) $\AA$ and 3.2995(5) $\AA$ (Fig. 2).

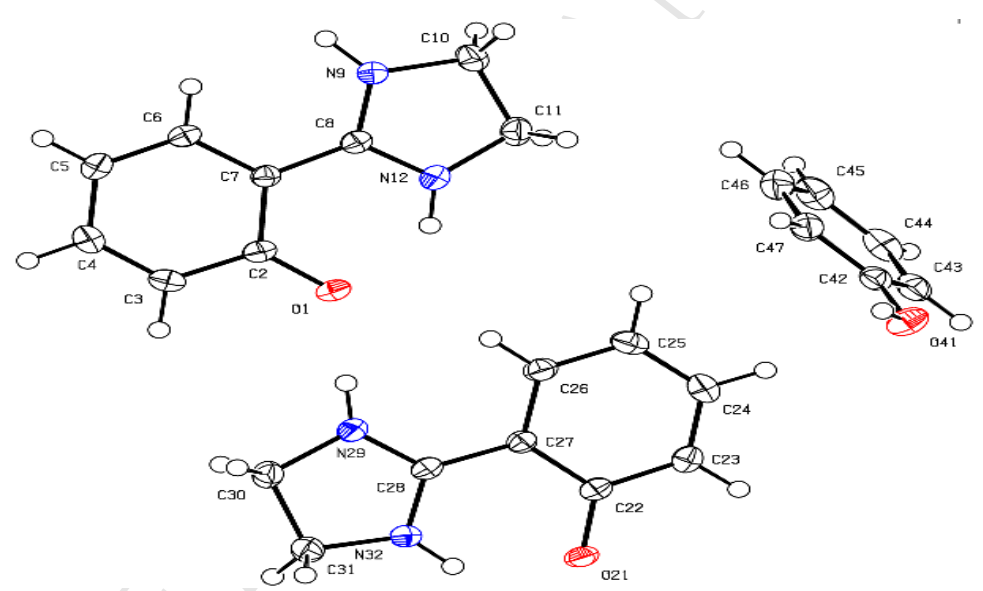

Fig. 1. An ORTEP reptesentation of L1 crystal with atom numbering scheme and 50\% probability ellipsoids for all non hydrogen atoms. 


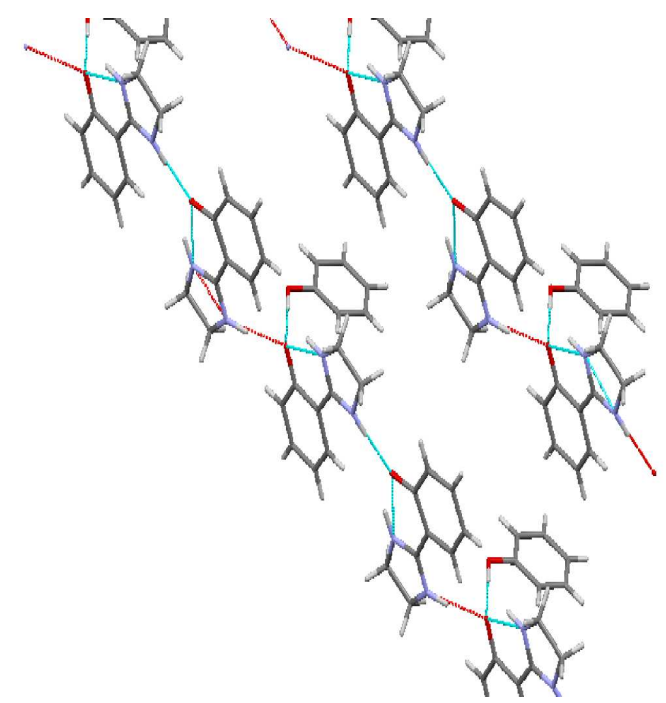

Fig. 2. Packing view of L1 crystal. Intramolecular hydrogen bonds showing the formation of $\mathrm{R}(6)$ rings with dashed blue lines $(\mathrm{N}-\mathrm{H} \ldots \mathrm{O})$. Intermolecular hydrogen bonds are shown as blue dashed lines $(\mathrm{N}-\mathrm{H} \ldots \mathrm{O}$ and $\mathrm{Ar}-\mathrm{O}-\mathrm{H} \ldots \mathrm{O})$. H-N...O interactions are dashed in red lines.

Table 1 Crystallographic data for and structure refinement parameters for L1

$$
\text { Empirical formula } \quad \mathrm{C}_{24} \mathrm{H}_{26} \mathrm{~N}_{4} \mathrm{O}_{3}
$$

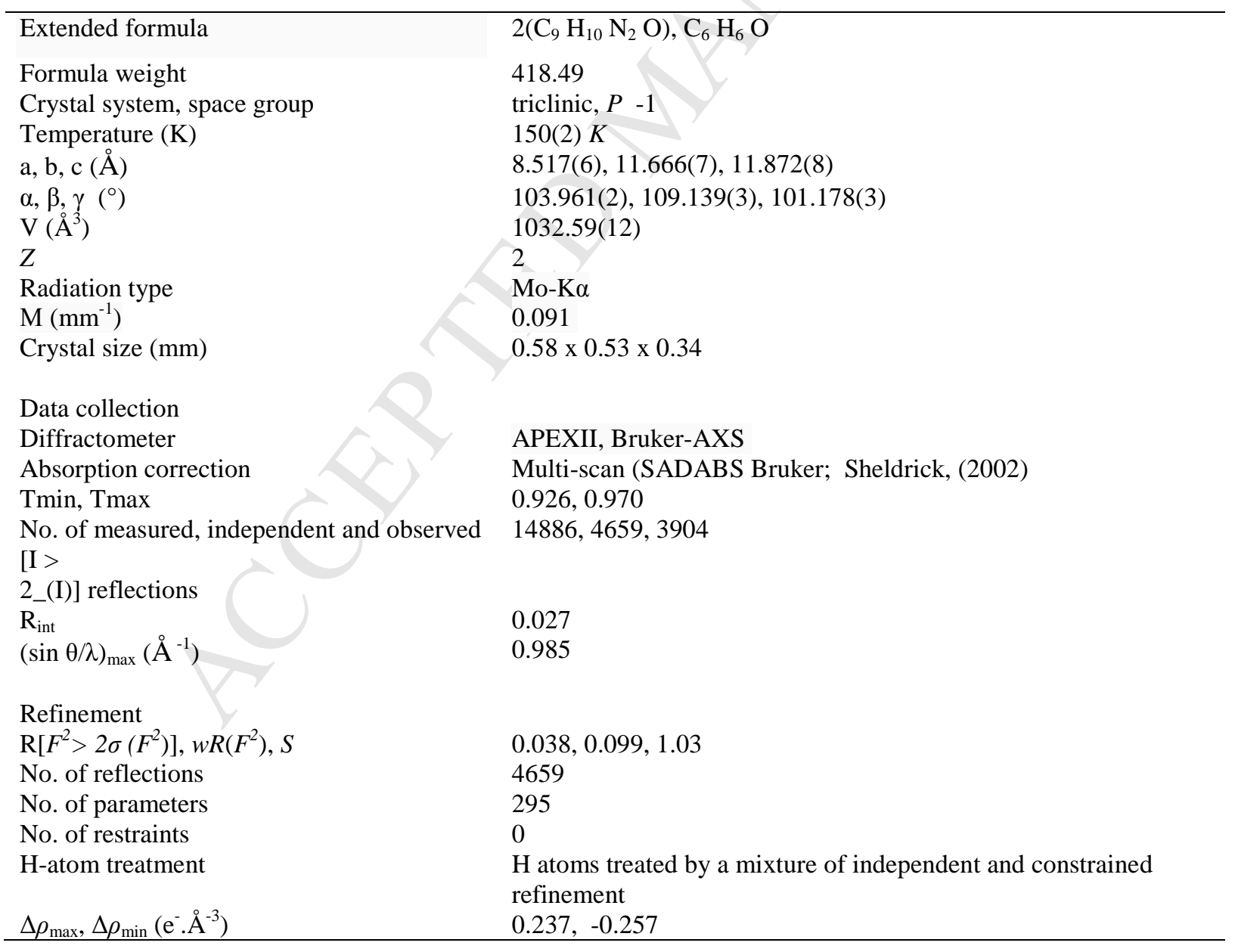


Table 2 Hydrogen bonds for L1

\begin{tabular}{clllll}
\hline & Hydrogen bonds & \multicolumn{3}{c}{ Distances $(\stackrel{\AA}{ })$} & Angles lenghts $\left(^{\circ}\right)$ \\
\hline Entry & $\mathrm{D}-\mathrm{H} \ldots \mathrm{A}$ & $\mathrm{d}(\mathrm{D}-\mathrm{H})$ & $\mathrm{d}(\mathrm{H} \ldots \mathrm{A})$ & $\mathrm{d}(\mathrm{D} \ldots \mathrm{A})$ & $\langle\mathrm{DHA}\rangle$ \\
\hline $\mathbf{1}$ & $\mathrm{N}_{9}-\mathrm{H}_{9} \ldots \mathrm{O}_{21}{ }^{\mathrm{i}}$ & $0.933(17)$ & $1.875(17)$ & $2.795(12)$ & $168.6(15)$ \\
$\mathbf{2}$ & $\mathrm{N}_{12}-\mathrm{H}_{12} \ldots \mathrm{O}_{1}$ & $0.918(17)$ & $1.843(17)$ & $2.585(13)$ & $136.3(14)$ \\
$\mathbf{3}$ & $\mathrm{N}_{29}-\mathrm{H}_{29} \ldots \mathrm{O}_{1}$ & $0.909(17)$ & $1.826(18)$ & $2.730(12)$ & 173.315 \\
$\mathbf{4}$ & $\mathrm{N}_{32}-\mathrm{H}_{32} \ldots \mathrm{O}_{21}$ & $0.904(17)$ & $1.903(17)$ & $2.621(12)$ & $134.9(14)$ \\
$\mathbf{5}$ & $\mathrm{O}_{41}-\mathrm{H}_{41} \ldots \mathrm{O}_{21}{ }_{i 1}$ & $0.929(17)$ & $1.744(17)$ & $2.672(11)$ & $177.3(15)$ \\
\hline
\end{tabular}

Symmetry codes: i) $1+\mathrm{x}, \mathrm{y}, 1+\mathrm{z}$; (ii) $1+\mathrm{x}, \mathrm{y}, \mathrm{z}$

\subsection{NMR spectroscopy and tautomerisation mechanism of 2-(1H-Imidazolin-2-yl)phenol}

The 2D structures are drawn with Chemdraw software. Phenol-imidazole and phenol molecules are shown in Scheme.1 with 2D numbering system adopted in this study.

The ${ }^{1} \mathrm{H}$ NMR spectrum of single crystal L1 is represented on Fig. S1. The phenolic protons are identified at $4.94 \mathrm{ppm}$. The aromatic protons of the phenol appear at: $6.53 \mathrm{ppm}$ for $\mathrm{C}_{14}-\underline{\mathrm{H}}_{14}$ and $\mathrm{C}_{18}-\underline{\mathrm{H}}_{18}, 6.80 \mathrm{ppm}$ for $\mathrm{C}_{15}-\underline{\mathrm{H}}_{15}$ and $\mathrm{C}_{17}-\underline{\mathrm{H}}_{17}$ and $6.49 \mathrm{ppm}$ for $\mathrm{C}_{16}-\underline{\mathrm{H}}_{16}$. The aromatic protons of the ligand appear at $6.47 \mathrm{pm}$ for $\mathrm{C}_{6}-\underline{\mathrm{H}}_{6}, 6.75 \mathrm{ppm}$ for $\mathrm{C}_{3}-\underline{\mathrm{H}}_{3}$ and $7.15 \mathrm{ppm}$ for $\mathrm{C}_{4}-\underline{\mathrm{H}}_{4}$ and $\mathrm{C}_{5}-\underline{\mathrm{H}}_{5}$. The imidazole ring is characterized by two types of peak: $\mathrm{C}_{10}-\underline{\mathrm{H}}_{10}$ and $\mathrm{C}_{11}-\underline{\mathrm{H}}_{11}$ at $3.90 \mathrm{ppm}$ and $\mathrm{N}-\mathrm{H}$ and $\mathrm{N}-\mathrm{H}$ protons at 7.44 and $7.42 \mathrm{ppm}$ respectively which is due to an environmental difference of the two nitrogen atoms (Scheme 2). Our results agree very well with those of literature [33].

The ${ }^{13} \mathrm{C}$ NMR spectrum of single crystal L1 is represented on Fig. S2. These data shows: i) first signal appears at $172.18 \mathrm{ppm}$ which is attributed to the carbonyl carbon $\left(\mathrm{C}_{1}\right)$ in the ketone-imidazolidine form; ii) signals from 107 to $157 \mathrm{ppm}$ are attributed to the aromatic nuclei carbons. The imidazole carbon atoms $\left(\underline{\mathrm{CH}}_{2}, \mathrm{C}_{10}\right.$ and $\left.\mathrm{C}_{11}\right)$ appear at $43.54 \mathrm{ppm}$ and the cyclic imine carbon $\left(\mathrm{C}_{8}\right)$ at $166.80 \mathrm{ppm}$ which justifies the formation of this ligand.

In solution and with solvent interaction, the zwitterionic form disappears and gives the 2-(4,5-dihydro-1H-imidazol-2-yl)phenol 1a,b which can quickly change its isomeric form to phenol-imidazole by tautomerization in ketone-imidazolidine form (6-(imidazolidin-2ylidene)cyclohexa-2,4-dienone 3) by hydrogen transfer from phenol to imine nitrogen through intramolecular hydrogen bonding via a chelate intermediate 2 .

In deuterated methanol $\left(\mathrm{CD}_{3} \mathrm{OD}\right)$, the 2-(4,5-dihydro-1H-imidazol-2-yl)phenol 1a,b and the 6-(imidazolidin-2-ylidene)cyclohexa-2,4-dienone $\mathbf{3}$ are in equilibrium between the two tautomer forms. The ratio of these tautomers is depending specially on the solvent, temperature and $\mathrm{pH}$. We propose the following tautomerisation mechanism given in Scheme 2. 


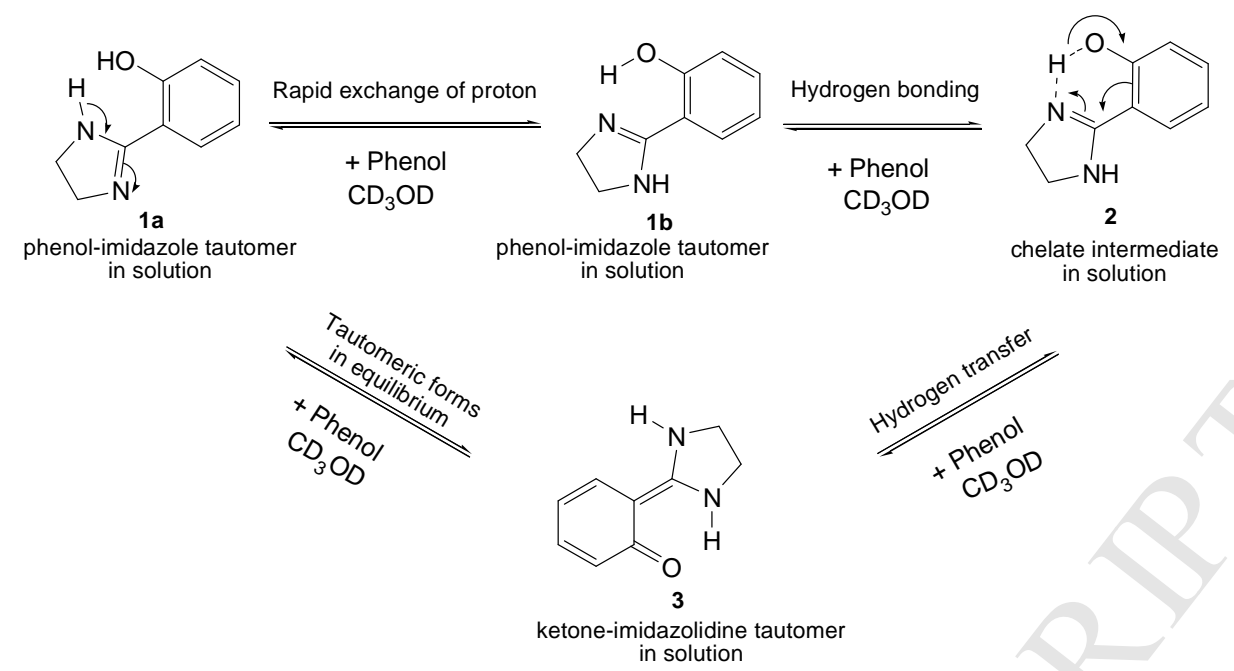

Scheme 2. Proposed keto-enolic tautomerisation mechanism in solution.

\subsection{UV/Vis L1 spectrophotometry of L1}

The figure 3 shows that the first and the second absorption bands in Nujol are higher than in methanol. Therefore, the first band at $240-260 \mathrm{~nm}$ is due to a $\pi \rightarrow \pi^{*}$ electron transition of the aromatic ring. The second band at 300-330 nm corresponds to a $\pi \rightarrow \pi^{*}$ transition involving the $\pi$-electrons of the imidazole and phenol groups.

From Figure 3, we note that the third 330-400 nm absorption band of Nujol is more intense than that at $330-370 \mathrm{~nm}$ of methanol. This reveals the presence of the ketoneimidazolidine and phenol-imidazole forms respectively. The Nujol third band decreases slowly indicating predominance of the corresponding ketone-imidazolidine form. The two curves reach a maximum at $250 \mathrm{~nm}$ which confirms the existence of two distinct tautomer forms in the UV/Vis spectrum of L1. These results indicate that the tautomerization occurs rapidly at the higher energy region $(330-400 \mathrm{~nm})$. Thus, we attribute that to the ketoneimidazolidine tautomer stabilized by intramolecular hydrogen bond (due to ketoneimidazolidine tautomer) and intermolecular hydrogen bonds (between phenol and ketoneimidazolidine tautomer, and phenol-imidazole/ketone-imidazolidine tautomers) of L1 (Scheme 2).

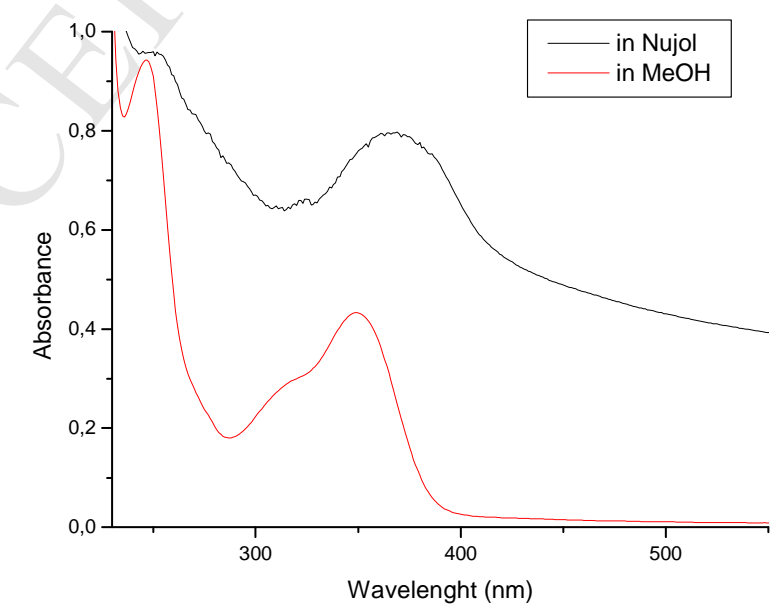

Fig.3. Absorption spectra of L1 in Nujol and in methanol. 


\subsection{Catalytic activity studies}

\subsubsection{Effect of the nature of the anion}

The kinetic study was performed according to the mode described in section 2.4. Results of kinetic study are reported in Table 3 . These values show high velocities for catalyst prepared with copper acetate salt, compared to sulfate, nitrate and chloride. This is related to a geometric structure created by the molecules of these salts and specially the acetate group around the copper center which can promote or prevent 3,5-DTBC approach to the catalyst, which is in agreement with the literature [18].

Table 3 Oxidation rates $\left(\mu \mathrm{mol} \cdot \mathrm{L}^{-1} \cdot \mathrm{min}^{-1}\right)$ of 3,5 -DTBC with in situ complex $(\mathrm{Cu} / \mathrm{L} 1)$

\begin{tabular}{cccccccc}
\hline & \multicolumn{7}{c}{$[\mathbf{3 , 5 - D T B C ]}$} \\
\cline { 2 - 7 } Copper salt & $10^{-2}$ & $2.10^{-2}$ & $3.10^{-2}$ & $4.10^{-2}$ & $5.10^{-2}$ & $6.10^{-2}$ & $7.10^{-2}$ \\
\cline { 2 - 8 } $\mathbf{C u}\left(\mathbf{C H}_{\mathbf{3}} \mathbf{C O O}\right)_{2}$ & 11.15 & 10.89 & 11.74 & 12.57 & 11.96 & 12.23 & 13.31 \\
$\mathbf{C u S O}_{4}$ & 4.89 & 4.87 & 5.84 & 6.52 & 6.07 & 6.19 & 7.13 \\
$\left.\mathbf{C u}_{\mathbf{N}} \mathbf{N O}_{3}\right)_{2}$ & 1.27 & 0.99 & 1.5 & 2.08 & 2.07 & 2.10 & 3.10 \\
$\mathbf{C u C l}_{2}$ & 1.593 & 1.07 & 1.302 & 1.49 & 1.20 & 1.31 & 1.71 \\
\hline
\end{tabular}

The Rate values in literature show high speed values for isolate complex $(1.93 \mu \mathrm{mol}$ $\mathrm{L}^{-1} \mathrm{~min}^{-1}$ ) [20]. We have obtained good result with our in situ complex CuL1 (derived from copper acetate and ligand L1) compared to those of the literature [18, 20, 26]. In addition, L1 ligand is composed from two planar phenol-imidazole molecules and one phenol molecule.

\subsubsection{Study of in situ complex structure and oxidation reaction of 3,5-DTBC}

First, we have studied the structure of in situ complex. The formation of the in situ complex of copper (II) was followed by the measurement of UV-visible absorption for $1 \mathrm{~h}$. An equimolar mixture $\left(10^{-4} \mathrm{~mol}\right)$ of ligand L1 and of copper (II) acetate was brought together in methanol. The progressive reaction gives two bands at $325 \mathrm{~nm}$ and $390 \mathrm{~nm}$ compared to the spectrum of the free ligand L1 (Fig.4a). These bands are attributed to ligand-metal charge transfer [36]. While two new bands appear at $570 \mathrm{~nm}$ and $725 \mathrm{~nm}$ (Fig.4b) which indicate respectively the presence in situ of binuclear specie around two copper centers: a distorted square pyramidal and a distorted octahedral respectively [30, 37].

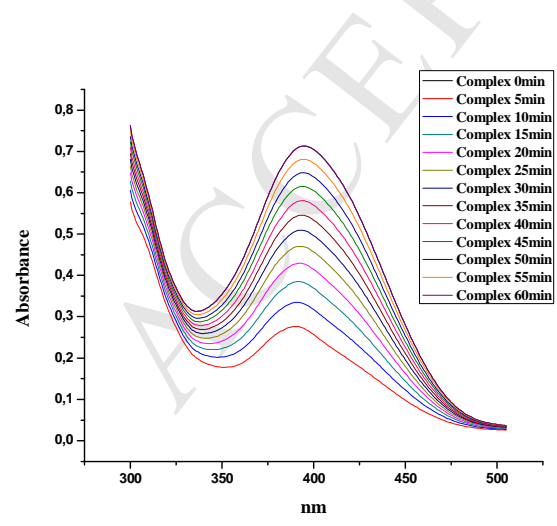

a)

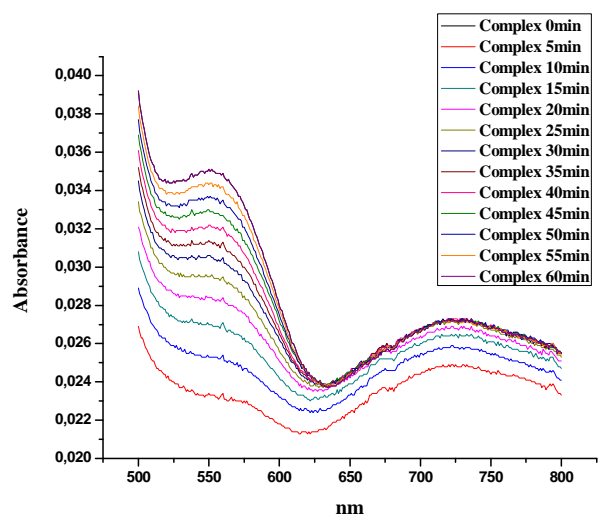

b)

Fig. 4. UV/Vis analysis for the in situ complex formation of L1 with copper (II) acetate over time: a) (300-600) nm; b) (500-800) nm. 
Second, we have determined the catecholase activity by the same in situ complex. The evolution of the oxidation reaction of 3,5-DTBC by the in situ complex is justified by the presence of the 3,5-DTBQ (Q) band at $410 \mathrm{~nm}$ (Fig. 5). From these results, we conclude that the structure of in situ complex L1 remains unchanged during the catechol oxidation.

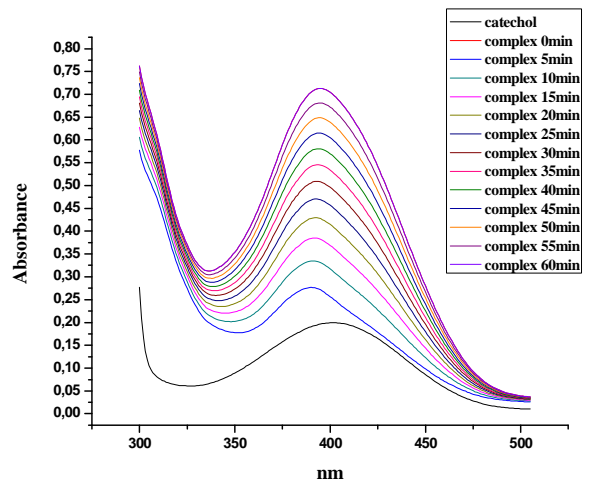

a)

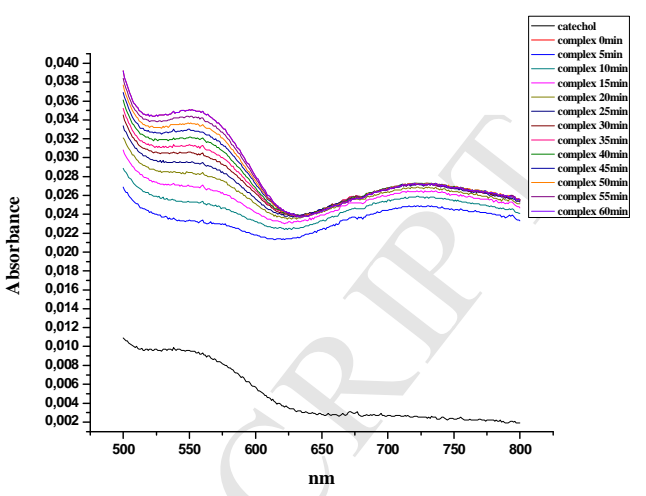

b)

Fig. 5. UV/Vis analysis of the 3,5-DTBC oxidation by in situ complex L1 with copper (II) acetate over time.

The Q crystal of 3,5-DTBQ is illustrated in Figure. 6. Q is crystallized in a triclinic space group $\mathrm{P}-1$ and with a two unit per cell $(\mathrm{Z}=2)$. The structure of $\mathrm{Q}$ is build by an asymmetric unit containing one water molecule and three 3,5-di-tert-butylquinone molecules.
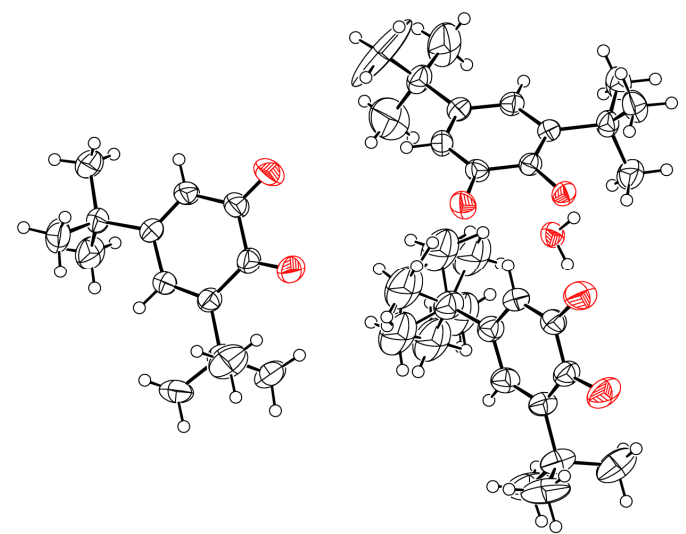

Fig. 6. An ORTEP representation of Q crystal with 50\% probability ellipsoids for all non hydrogen atoms.

\subsubsection{Michaelis-Menten kinetics}

The catalytic activity of a complex can be evaluated by determining the kinetic parameters of the oxidation reaction. Thus, oxidation rates were determined by the initial rate method then analyzed with Michaelis-Menten model which is commonly used in enzymatic catalysis [38, 39]. Parameters for the oxidation reaction were determined. The oxidation reaction in the presence and absence of the catalyst, were carried out under the same concentration conditions described in section 2.4. The velocity values obtained in the absence of the catalyst are subtracted from those in their presence. Figure 7 shows the MichaelisMenten plots of the 3,5-DTBC oxidation reaction catalyzed by in situ complex CuL1 (obtained from $\mathrm{Cu}(\mathrm{AcO})_{2}$ and L1). Table 4 summarizes the results of this study. 


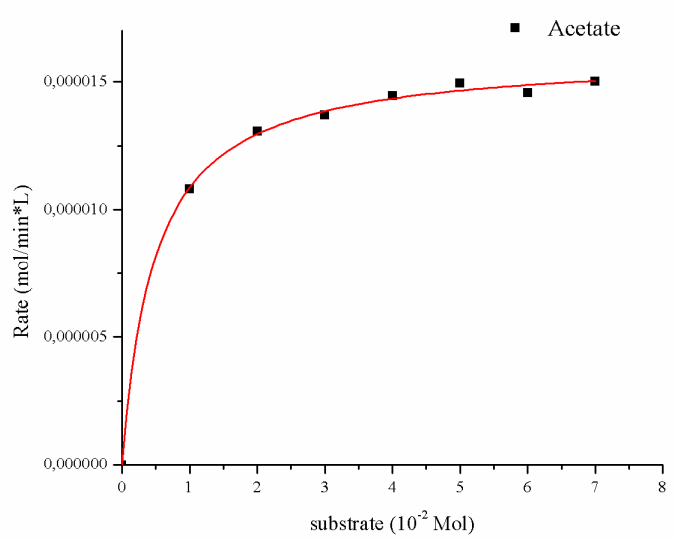

Fig.7. Kinetic study of the 3,5-DTBC oxidation by in situ CuL1 complex.

The kinetic model of in situ complex follows the simple Michaelis-Menten mechanism. The plot $1 /$ [v] = f $1 /$ [3,5-DTBC] gives a straight line from which the complexsubstrate dissociation constant (Kcat) and the Michaelis bond constant (Km) are evaluated. As indicated in Table 4, the in situ complex CuL1 shows a higher activity $\mathrm{V}_{\max }=1.61 .10^{-5}$ mol.min ${ }^{-1} \mathrm{~L}^{-1}$ and $\mathrm{K}_{\mathrm{cat}}=9,64 \mathrm{~h}^{-1}$, which is related to nature of bonds formed in the in situ complex.

The literature shows a wide range of examples of catecholase activity, the most active of which are binuclear complexes $[40,44]$. The Kcat value 9,64 $\mathrm{h}^{-1}$ observed from CuL1 proves the capacity of this complex for the catalytic oxidation of 3,5-DTBC, which is in some cases similar or even superior to some dinuclear [20, 45].

Table 4. Kinetic parameters of 3,5-DTBC oxidation with in situ CuL1 complex

\begin{tabular}{cccccc}
\hline In situ Complex & Copper salt & $\mathbf{V}_{\max }\left(\mathbf{M} \cdot \mathbf{m n}^{-1}\right)$ & $\mathbf{K}_{\text {cat }}\left(\mathbf{h}^{-1}\right)$ & $\mathbf{K}_{\mathbf{M}}(\mathbf{M})$ & $\mathbf{K}_{\text {cat }} / \mathbf{K}_{\mathbf{M}}\left(\mathbf{h}^{-1} \cdot \mathbf{M}^{-1}\right)$ \\
\hline $\mathbf{C u L 1}$ & $\mathrm{Cu}(\mathrm{AcO})_{2}$ & $1,61.10^{-5}$ & 9,66 & $0,48 \times 10^{-2}$ & $20,12 \times 10^{2}$ \\
\hline
\end{tabular}

\subsubsection{Structure-activity relationship}

We have also studying the action of the free ligand L1 on the 3,5-DTBC. In Figure 8, we have plotted the evolution of 3,5-DTBC oxidation in the presence of in situ acetate copper complex CuL1 and the synthesized ligand L1. Comparing the two curves, we note that the $\mathrm{CuL} 1$ catalyst is 186 times more active than the ligand L1. Figure 8 shows an almost zero absorbance versus time in the absence of the catalyst under the same experimental conditions. Consequently, we confirm that 3,5-DTBC does not undergo oxidation in the absence of the copper catalyst and the ligand L1 alone does not allow oxidation. The oxidation rates are given in Table 5 . 


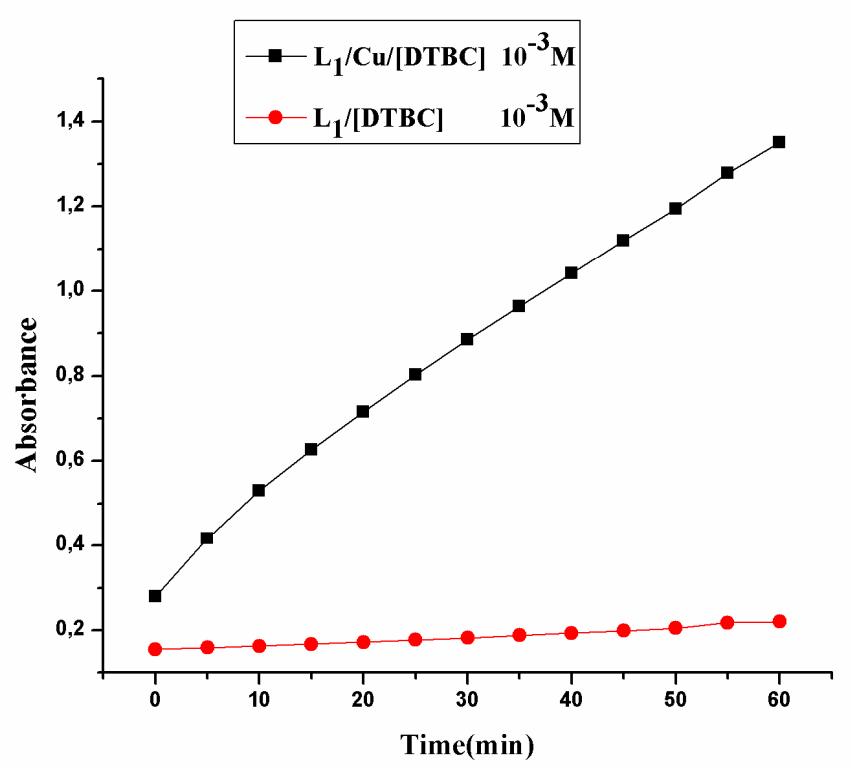

Fig. 8. Comparative study of $3,5-\mathrm{DTBC}$ catalytic oxidation by the ligand and the corresponding complex.

Table 5 Oxidation rates $\left(\mu \mathrm{mol} \mathrm{L} \mathrm{Lin}^{-1}\right)$ of 3,5-DTBC with ligand $\mathrm{L} 1$ and in situ CuL1 complex.

\begin{tabular}{ccc}
\hline Compound & In situ CuL1Complex & Ligand $\mathbf{L}_{\mathbf{1}}$ \\
\hline Rate & 11.15 & 0.06 \\
\hline
\end{tabular}

A comparative study between the catalytic activities of in situ complexes and complexes with those of the literature showed that the ligand geometry has strong influence on their catalytic efficiency $[18,20]$. The geometry structure promotes the formation of a complex that does not present steric hindrance and facilitates the 3,5-DTBC approach and its oxidation [46].

\section{Conclusion}

We have synthesized the imidazole-derived ligand L1 which was characterized by single crystal X-ray diffraction, and by spectroscopic techniques (1H, 13C NMR, FT-IR, ESIMS, and UV-Vis). The asymmetric unit contains one phenol molecule and two imidazole phenolate molecules. Angle analysis justify that the molecules are practically planar and are connected via intermolecular and intramolecular hydrogen bonds forming zigzag chains layers. From NMR analysis, we have shown that equilibrium is created between the tautomers of L1: zwitterion and ketone-imidazolidine forms.

The oxidation of 3,5-DTBC to the corresponding ortho-quinone was carried out via the in situ copper (II) complex. The formation of 3,5-DTBQ characterized by single crystal Xray diffraction attested the ability of in situ complex to promote catechol oxidation. We have shown that the catalytic activity of our complex is influenced by the salt structure and by the steric and electronic effects of the ligand. The study of the structure-activity relationship show that the high rate of catalytic oxidation depends on the presence of copper ion in the complex.

We conclude that our in situ CuL1 complex can be considered as a good catalyst compared to some mononuclear or binuclear copper in situ or isolated complexes of the literature. 


\section{Supplementary Information}

CCDC No. 1061105 and CCDC No 1812752 can be obtained free of charge via http://www.ccdc.cam.ac.uk/conts/ retrieving.html.

\section{Acknowledgment}

Authors acknowledge the Algerian Ministry for Education and Research.

\section{References}

[1] S. Louhibi, A. Yacouta Nour, L. Vendier, J-P. Costes, J-P. Tuchagues, Polynuclear 3d complexes based on potentially tetra-anionic heptadentate ligands including amido, amino and phenoxo donors: Synthesis, crystal structure and magnetic properties. Polyhedron 26 (2007) 3448-3454. doi.org/10.1016/j.poly.2007.03.051

[2] K.S. Ashish, K. Prashant, Y. Mahendra, S.P. Daya, Synthesis, characterisation and theoretical studies on some piano-stool ruthenium and rhodium complexes containing substituted phenyl imidazole ligands. J. Organomet. Chem. 695 (2010) 567-573. doi.org/10.1016/j.jorganchem.2009.11.011

[3] M.C. Rodriguez-Argüelles, S. Mosquera-Vazquez, J. Sanmartin-Matalobos, A.M. Garcia eibe, C. Pelizzi, F. Zani, Evaluation of the antimicrobial activity of some chloro complexes of imidazole-2-carbaldehyde semicarbazone: X-ray crystal structure of cis$\mathrm{NiCl}_{2}\left(\mathrm{H}_{2} \mathrm{~L}\right)\left(\mathrm{H}_{2} \mathrm{O}\right)$. Polyhedron 29 (2010) 864-870. doi.org/10.1016/j.poly.2009.10.011

[4] J. Dietrich, V. Gokhale, X. Wanga, L. Hurley, G. Flynn, Application of a novel [3+2] cycloaddition reaction to prepare substituted imidazoles and their use in the design of potent DFG-out allosteric B-Raf inhibitors. Bioorg. Med. Chem. 18 (2010) 292-304. doi.org/10.1016/j.bmc.2009.10.055

[5] P. Nshimyumukiza, E. Van Den Berge, B. Delest, T. Mijatovic, R. Kiss, J. Marchand Brynaert, R. Robiette, Synthesis and biological evaluation of novel imidazole-containing macrocycles. Tetrahedron 66 (2010) 4515-4520. doi.org/10.1016/j.tet.2010.04.070

[6] G. Monod, A. DE Mones, A. Fostier, Inhibition of ovarian microsomal aromatase and follicular oestradiol secretion by imidazole fungicides in Rainbow trout. Mar. Environ. Res. 35 (1993) 153-157. doi.org/10.1016/0141-1136(93)90030-4

[7] G. Monod, H. Rime, J. Bob, B. Jalabert, Agonistic effect of imidazole and triazole fungicides on in vitro oocyte maturation in rainbow trout (Oncorhynchus mykiss). Mar. Environ. Res. 58 (2004) 143-146. doi.org/10.1016/j.marenvres.2004.03.008

[8] P. Ernsberger, J. E. Friedman, R. J. Koletsky. The I1-imidazoline receptor: from binding site to therapeutic target in cardiovascular disease. J. Hypertens. Suppl. 15 (1997) S9S23. doi.10.1097/00004872-199715011-00002

[9] D. Bajpai and V. K. Tyagi, Synthesis and characterization of imidazolinium surfactants derived from tallow fatty acids and diethylenetriamine. Eur. J. Lipid Sci. Technol. 110 (2008) 935-940. doi.org/10.1002/ejlt.200800046

[10] K. Kamaraj, E. Kim, B. Galliker, L. N. Zakharov, A. L.Rheingold, A. D. Zuberbu hler, and K. D. Karlin, Copper(I) and copper(II) complexes possessing cross-linked Imidazolephenol ligands: Structures and dioxygen reactivity. J. Am. Chem. Soc. 125 (2003) 60286029. doi.org/10.1021/ja034263f

[11] Y. Yoshida, N. Aoyagi, T. Endo, Substituent dependence of imidazoline derivatives on capture and release system of carbon dioxide. New J. Chem., 41 (2017) 14390-14396. doi.org/10.1039/C7NJ03133E

[12] M. H. Habibi, E. Shojaee, M. Ranjbar, H. Reza Memarian, A. Kanayama, T. Suzuki, Computational and spectroscopic studies of a new Schiff base 3-hydroxy-4methoxybenzylidene(2-hydroxyphenyl)amine and molecular structure of its 
corresponding zwitterionic form. Spectrochim. Acta A 105 (2013) 563-568. doi.org/10.1016/j.saa.2012.12.054

[13] S. Das, S. Santra, P. Mondal, A. Majee, A. Hajra, Zwitterionic imidazolium salt: Recent advances in organocatalysis. Synthesis 48 (2016) 1253-1420. doi.org/10.1055/s-0035$\underline{1561336}$

[14] M. Merkel, M., N. Möller, M. Piacenza, S. Grimme, A. Rompel, B. Krebs, Less symmetrical dicopper(II) complexes as catechol oxidase models-an adjacent thioether group increases catecholase activity. Chem. Eur. J. 11 (2005) 1201-1209. doi.org/10.1002/chem. 200400768

[15] I.A. Koval, P. Gamez, C. Belle, K. Selmeczi, J. Reedijk, Synthetic models of the active site of catechol oxidase: mechanistic studies. Chem. Soc. Rev. 35 (2006) 814-840. doi.org/10.1039/b516250p

[16] Y. Thio, X. Yang, J.J. Vittal, Influence of inductive effects and steric encumbrance on the catecholase activities of copper(II) complexes of reduced Schiff base ligands. Dalton Trans. 43 (2014) 3545-3556. doi.org/10.1039/C3DT52829D

[17] A. Biswas, L.K. Das, M.G.B. Drew, C. Diaz, A. Ghosh, Insertion of a Hydroxido bridge into a diphenoxido dinuclear copper(II) complex: Drastic change of the magnetic property from strong antiferromagnetic to ferromagnetic and enhancement in the catecholase activity. Inorg. Chem. 51 (2012) 10111-10121. doi.org/10.1021/ic300319s

[18] A. Mouadili, A. Attayibat, S. El Kadiri, S. Radi, R. Touzani, Catecholase activity investigations using in situ copper complexes with pyrazole and pyridine based ligands. Appl. Catal. A-Gen. 454 (2013) 93-99. doi.org/10.1016/j.apcata.2013.01.011

[19] I. Bouabdallah, R. Touzani, I. Zidane, A. Ramdani, Synthesis of new tripodal ligand: N,N-bis[(1,5-dimethylpyrazol-3-yl)methyl]benzylamine.: Catecholase activity of two series of tripodal ligands with some copper (II) salts. Catal. Commun. 8 (2007) 707-712. doi.org/10.1016/j.catcom.2006.08.034

[20] R. Marion, N.M. Saleh, N. Le poul, D. Floner, O. Lavastre, F. Geneste, Rate enhancement of the catechol oxidase activity of a series of biomimetic monocopper(II) complexes by introduction of non-coordinating groups in N-tripodal ligands. New J. Chem. 36 (2012) 1828-1835. doi.org/10.1039/C2NJ40265C

[21] M.R. Mendoza-Quijano, G. Ferrer-Sueta, M. Flores-A'lamo, N. Aliaga-Alcalde, V. Gomez-Vidales, V.M. Ugalde-Saldivara, L. Gasque, Mechanistic insight on the catecholase activity of dinuclear copper complexes with distant metal centers. Dalton Trans. 41 (2012) 4985-4997. doi.org/10.1039/c2dt12155g

[22] K.S. Banu, T. Chattopadhyay, A. Banerjee, S. Bhattacharya, E. Zangrando, D. Das, Catechol oxidase activity of dinuclear copper(II) complexes of Robson type macrocyclic ligands: Syntheses, X-ray crystal structure, spectroscopic characterization of the adducts and kinetic studies. J. Mol. Catal. A: Chem. 310 (2009) 34-41. doi.org/10.1016/j.molcata.2009.05.016

[23] M. Maiti, S. Sadhukhan, S. Thakurta, E. Zangrando, G. Pilet, A. Bauzá, A. Frontera, B. Dede, S. Mitra, Synthesis, structural characterization, theoretical calculations and catecholase mimetic activity of manganese-Schiff base complexes. Polyhedron. 75 (2014) 40-49. doi.org/10.1016/j.poly.2014.03.005

[24] M.R. Malachowski, M.G. Davidson, Novel mono- and binuclear $\mathrm{Cu}(\mathrm{II})$ complexes: synthesis, characterization and catecholase activity. Inorg. Chim. Acta, 162 (1989) 199204. doi.org/10.1016/S0020-1693(00)83147-3

[25] V. K. Bhardwaj, N. Aliaga-Alcalde, M. Corbella, G. Hundal, Synthesis, crystal structure, spectral and magnetic studies and catecholase activity of copper(II) complexes with diand tri-podal ligands. Chim. Acta. 363 (2010) 97-106. doi.org/10.1016/j.ica.2009.09.041 
[26] H. Boulemche , B. Anak, A. Djedouani, R. Touzani, M. François, S. Fleutot, F. Rabilloud, Synthesis, X-ray crystallography, computational studies and catecholase activity of new zwitterionic Schiff base derivatives. J. Mol. Struct. 1178 (2019) 606-616. doi.org/10.1016/j.molstruc.2018.10.078

[27] A. Altomare, M.C. Burla, M. Camalli, G. Cascarano, C. Giacovazzo, A. Guagliardi, A. G. G. Moliterni, G. Polidori, R. Spagna, SIR97: A new tool for crystal structure determination and refinement. J. Appl. Cryst. 32 (1999) 115-119. doi.org/10.1107/S0021889898007717

[28] G. M. Sheldrick, A short history of SHELX, Acta Cryst. A64 (2008) 112-122. doi.org/10.1107/S0108767307043930

[29] L. J. Farrugia, WinGX suite for small-molecule single-crystal crystallography. J. Appl. Cryst. 32 (1999) 837-838. doi.org/10.1107/S0021889899006020

[30] I. Belfilali, S. Louhibi, R. Mahboub, R. Touzani, S. El Kadiri, T. Roisnel, Study of the histamine copper(II) chloride complex catalytic activity. Chem. Intermed. 41 (2015) 1819-1831. doi.org/10.1007/s11164-013-1314-X

[31] A. Sapegin, A. Osipyan, M. Krasavin, Structurally diverse arene-fused ten-membered lactams accessed via hydrolytic imidazoline ring expansion. Org. Biomol. Chem. 15 (2017) 2906-2909. doi.org/10.1039/x0xx00000x

[32] K. Karamysheva, E. Reutskaya, A. Sapegin, M. Dorogov, M. Krasavin, Atomeconomical construction of tetracyclic [1,4] oxazepines involving intramolecular arylation of a 2-imidazoline moiety. Tetrahedron Lett., $56 \quad$ (2015) 5632-5637. doi.org/10.1016/j.tetlet.2015.08.062

[33] Z. Gan, K. Kawamura, K. Eda, M. Hayashi, Effect of ortho-substituents on the stereochemistry of 2-(o-substituted phenyl)-1H-imidazolineepalladium complexes. J. Organomet. Chem. 695 (2010) 2022-2029. doi:10.1016/j.jorganchem.2010.05.007

[34] R. Mitsuhashi, T. Suzuki, Y. Sunatsuki, Four-Electron Oxidative dehydrogenation induced by proton-coupled electron transfer in ruthenium(III) complex with 2-(1,4,5,6tetrahydropyrimidin-2-yl)phenolate. Inorg. Chem. 52 (2013) 10183-10190. doi.org/10.1021/ic401667v

[35] I. Belfilali, S. Yebdri, S. Louhibi, L. Boukli-hacene, T. Roisnel, Crystal structure of 2(1H-imidazol-4-yl)- ethanaminium chloride. Acta Cryst. E71 (2015) o301-o302. doi.org/10.1107/S2056989015006866

[36] K. S. Banua, T. Chattopadhyaya, A. Banerjeea, Catechol oxidase activity of dinuclear copper(II) complexes of Robson type macrocyclic ligands: Syntheses, X-ray crystal structure, spectroscopic characterization of the adducts and kinetic studies. J. Mol. Catal. Chem. 310 (2009) 34-41. doi.org/10.1016/j.molcata.2009.05.016

[37] U. Mukhopadhyay, L. Govindasamy, K. Ravikumar, D. Velmurugan, D. Ray, Synthesis and structural characterization of a triply bridged copper(II)-zinc(II) Schiff base complex with N,O coordination. Inorg. Chem. Commun. 1 (1998) 152-154. doi.org./ 10.1016/S1387-7003(98)00040-9

[38] A. Granata, E. Monzani, L. Casella, Mechanistic insight into the catechol oxidase activity by a biomimetic dinuclear copper complex. J. Biol. Inorg. Chem. 9 (2004) 903 913. doi.org/10.1007/s00775-004-0595-3

[39] S. K. Mal, M.Mitra, H.R. Yadav, C. S. Purohit, A. R. Choudhury, R. Ghosh, Synthesis, crystal structure and catecholase activity of a vanadium(V) Schiff base complex. Polyhedron. 111 (2016) 118-122. doi.org/10.1016/j.poly.2016.03.033

[40] S.K. Dey, A. Mukherjee, Catechol oxidase and phenoxazinone synthase: Biomimetic functional models and mechanistic studies. Coord. Chem. Rev. 310 (2016) 80-115. doi.org/10.1016/j.ccr.2015.11.002 
[41] K.S. Banu, T. Chattopadhyay, A. Banerjee, S. Bhattacharya, E. Suresh, M. Nethaji, N. Zangrando, D. Das, Catechol oxidase activity of a series of new dinuclear copper(II) complexes with 3,5-DTBC and TCC as substrates: Syntheses, X-ray crystal structures, spectroscopic characterization of the adducts and kinetic studies. Inorg. Chem. 47 (2008) 7083-7093. doi.org/10.1021/ic701332w

[42] Casellato, P.A. Vigato, A. De Stefani, M. Vidali, D.E. Fenton, The preparation of binuclear complexes and their catalytic behaviour in the oxidation of 3,5-di-butycatechol. Inorg. Chim. Acta 69 (1983) 45-51. doi.org/10.1016/S0020-1693(00)83550-1

[43] I. Koval, K. Schilden, A.M. Schuitema, P. Gamez, C. Belle, J.L. Pierre, M. Lüken, B. Krebs, O. Roubeau, J. Reedijk, Proton NMR spectroscopy and magnetic properties of a solution-stable dicopper(II) complex bearing a single $\mu$-hydroxo bridge. Inorg. Chem. 44 (2005) 4372-4382. doi.org/10.1021/ic0501770

[44] S. Sarkar, A. Sim, S/ Kim, H. Lee, Catecholase activity of a self-assembling dimeric $\mathrm{Cu}$ (II) complex with distant $\mathrm{Cu}$ (II) centers. J. Mol. Catal. Chem. 410 (2015) 149-159. doi.org/10.1016/j.molcata.2015.08.007

[45] P. Gentschev, N. Moller, B. Krebs, New functional models for catechol oxidases. Inorg. Chim. Acta. 300 (2000) 442-452. doi.org/10.1016/S0020-1693(99)00553-8

[46] H. Keypour, M. Shayesteh, M. Rezaeivala, F. Chalabian, Y. Elerman, O. Buyukgungor, Synthesis, spectral characterization, structural investigation and antimicrobial studies of mononuclear $\mathrm{Cu}(\mathrm{II}), \mathrm{Ni}(\mathrm{II}), \mathrm{Co}(\mathrm{II}), \mathrm{Zn}(\mathrm{II})$ and $\mathrm{Cd}(\mathrm{II})$ complexes of a new potentially hexadentate $\mathrm{N}_{2} \mathrm{O}_{4}$ Schiff base ligand derived from salicylaldehyde. J. Mol. Struct. 1032 (2013) 62-68. doi.org/10.1016/j.molstruc.2012.07.056 


\section{Highlights}

- Synthesis of zwitterionic imidazole derivative

- Crystal form of ligand L1.

- Catecholase activity studies by in situ copper complexes. 